\title{
Essay
}

\section{The Long Walk}

\section{Migrant Workers and Extreme Mobility in the Age of Corona}

\author{
Pramod K. Nayar \\ University of Hyderabad, India
}

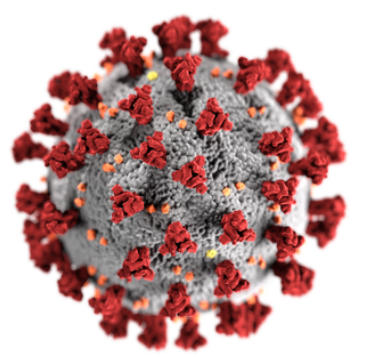

The Covid-19 pandemic has made a commonplace of the carceral imaginary. Isolation, social distancing, and quarantine have become watchwords. Physician instructions, epidemiologist advice, and state orders jostle alongside memes and jokes about being under 'lockdown', barricaded-in and homebound across the world. An immobility regime dominates now with cancelled airline, bus and train services. Yet, the same regime has generated an extreme mobility in nations like India, particularly in cities like New Delhi.

Reports of migrant workers walking hundreds of kilometres to their hometowns as a result of the lockdown - to last 21 days, as of now - from cities like New Delhi and the National Capital Region (NCR) have appeared in the newspapers (Agarwal 2020; also see Shroff 2020). The report interviewed some of these workers:

No work meant no wage and no wage meant no food. "There would have been no way for us to survive," Vipin said. The group had only begun its latest assignment at a construction site in Noida's Mamura on March 16.

"Whatever money we had earnt in that week, we spent on food after March 22. Now we only have Rs 500 between the fifteen of 
Pramod K. Nayar - The Long Walk

us," said Vipin. "We had two options - to either stay in Noida

and starve, or try and walk back home" ( (Agarwal). ${ }^{1}$

Reports like the above present several points of interest, which I shall outline in the form of three brief propositions.

\section{Hyperincarceration}

Migrant workers across the Indian metropolises are always already in a hyperincarcerated mode. $^{2}$

Dominique Moran and Anna Schliehe describe 'the space of the metropolitan centre, and the ways in which the spaces of the prison open out into these urban spaces of marginality in the context of hyperincarceration'. In these conditions, they write, building on the work of Caleb Smith, the city's clean zones are the result of the 'exclusion of criminalised underclasses' from these spaces (Moran and Schliehe 2017: 5). The urban poor, of which the migrant workers constitute a major class, experience this hyperincarceration.

Trapped within vicious economic and social marginalization, laid off at will, underpaid, often illegally hired, the migrant worker is always already at risk with the likely closure of the unit, its relocation, among other factors (Ramaswami 2012, also Heitzman 2004). Their hyperincarceration is not for criminalized behaviour but by virtue of their severe exclusion from and entrapment within the urban spaces of these cities. One report notes:

While poor working and living conditions, marked by deplorable access to clean drinking water and sanitation facilities, are a grim reality for all construction workers, women and children particularly suffer multiple deprivations on account of lack of daycare/ creche facilities, and lack of medical leave, health insurance and maternity benefits (Roy 2017: 5).

Further, because they are mobile in search of employment, they often fail to vote and hence are not part of the political process (Aajeevika 2016).

Hyperincarceration may then be said to be the state of precarity in which migrant workers' lives are lived. Hyperincarceration consists of invisible practices of isolation and exclusion since it is a condition of people whose lives do not matter - it is extreme in the sense that it is never visible and yet tangible in terms of the conditions in which the workers live.

\section{Stuckedness and Extreme Agency}

For the migrants, the arrival of the virus has generated an extraordinary state of what Ghassan Hage has termed 'stuckedness' (Hage 2009). Hage proposes that 
the migrant seeks 'existential mobility' to avert 'existential immobility', or stuckedness. For Hage, this stuckedness, especially in the case of migrants, has been normalized. This means, the ones who are stuck have to simply 'wait it out' - or wait for the crisis to blow over. What does this stuckedness mean for the migrant worker embarking on her/his perilous journey in the age of Corona?

For the migrant workers, staying on in New Delhi was not an option, since their wages had stopped and there was no work to be found. The lockdown proscribed all movement. As one report put it, 'fearing the spread of the infection, police officials asked many workers not to make the journey' (Livemint). In short, the workers were being told to wait out the crisis, and their mobility would put the nation at risk - by spreading the infection. One such worker said, 'either we stay and die, or leave and die' (Slater and Masih 2020).

The paradigm of heroic stuckedness that frames the conditions of the migrant workers expects them to endure and prevail in the most horrific of conditions - no wages, no food, no jobs and a virus on the move. That is, to endure immobilization in these conditions is to adapt to a loss of agency. Further, the law-and-order machinery's insistence on staying put with no resources at their disposal implies an extreme governmentality itself. Hage points out:

enduring the crisis becomes the normal mode of being a good citizen and the more one is capable of enduring a crisis the more of a good citizen one is. As usual this takes on a racial, civilizational and class dimension: the ones who do not know how to wait are the 'lower classes', the uncivilised and racialised others. The civilised, approximating the image of the hero, are those who get stuck in a classy way. They know how to endure (Hage 2009:105).

It is in the face of such stuckedness and its loss of agency that the migrant workers have enunciated their version of agency: walking 600 miles (Slater and Masih) to their homes with no money in their pockets and a marauding virus spreading across the nation.

If, as Hage proposes, the very act of enduring stuckedness is treated as a sign of agency, then the act of setting out on an improbably long walk with non-existent resources may easily qualify as extreme agency. It is this extreme agency that manifests as the precarious and long walk the migrant has set out on, this last week in India.

\section{The Rise of Extreme Mobility}

The state has ordered people to stay and work from home. A new isolation discourse is in operation around the world and India is no exception. 
Pramod K. Nayar - The Long Walk

Alison Bashford and Carolyn Strange writing about the cultural, medical and legal politics of isolation observe:

Coerced exclusion is intricately connected with modernity, with citizenship, with territory, with biopolitical governance of national, colonial and postcolonial populations. The proliferation of prisons, asylums, isolation hospitals and racially segregated zones over the nineteenth and twentieth centuries bears witness to the modern state's ambition to track, know and manage populations (Bashford and Strange 2003: 4).

Isolation was a mode of tracking and managing populations: but what of populations who were never factored into the equation, as seems to be the case now?

When immobility regimes such as lockdowns are put in place, there is a significant segment of the city's population - the floating migrant workers - for whom a whole new regime is instituted. Thus, the lockdown and isolation of those with houses and homes also unwittingly and uncaringly introduces an extreme mobility regime for the poor migrants in the city who are evicted from jobs and their temporary accommodations, and forced to 'march' enormous distances - and the temperatures in the NCR region are already rising, at $24-29^{\circ} \mathrm{C}$.

I term this extreme mobility because (i) it is resonant with older forms of forced migrations due to economic crisis, political persecution or bonded labour/slavery and (ii) the conditions in which the actual mobility occurs are extreme, as the above comments by the workers indicate.

Further, the mobility forced upon the migrant workers only implies an escape from the lockdowns in the NCR. Where they are headed to - their hometowns in rural Uttar Pradesh, Bihar and other regions of northern India - is marked by poverty of unmitigated scales (which is what drives the migrant to the city in the first instance). I have argued elsewhere that immobility is what constitutes extreme conditions of torture where the illusion of a possible escape is presented. In such cases,

immobility regimes transfor $[\mathrm{m}]$... movement into dying moments. Immobility regimes in these films and representations, I propose, are modes of intensifying terrifying territoriality, because an escape route is kept open, or identified, only to ensure the protagonists' death (Nayar 2017: 2).

If isolation and immobility marked the torture films' amplification of the horrors perpetrated on the victim, in the case of migrants marching, it is mobility that amplifies their helplessness because the illusion of escaping a lockdown is neutralized by the irreducible fact of the loss of income and extreme penury with which they head home. 
Pramod K. Nayar - The Long Walk

The extreme mobility regime extends the carceral imaginary, manifest as hyperincarceration, already in place around the poor migrant worker, and forces her to adopt an extreme agency in the face of enforced stuckedness. This appears the right time to examine instances of extreme anthropological models among such a people.

\section{References}

Aajeevika Bureau. 2016. 'Political Inclusion of Seasonal Migrant Workers in India: Perceptions, Realities and Challenges'. Aajeevika Bureau. http:// www.shram.org//shrampublications/shramreports/searchspreport/? $\underline{\text { searchType }=\& \text { themeSelect }=\text { \&orgSelect }=\& \text { searchtitle }=\& \text { actionSearch }=\mathrm{GO}}$

Agarwal, Kabir. 2020. 'Hunger Can Kill Us Before the Virus': Migrant Workers on the March During Lockdown', The Wire 27 March 2020. https:// thewire.in/labour/coronavirus-lockdown-migrant-workers-walking-home

Bashford, Alison and Carolyn Strange. 2003. 'Isolation and exclusion in the modern world: An introductory essay', in Bashford and Strange (eds) Isolation: Places and practices of exclusion. London and New York: Routledge, 1-18. https://doi.org/10.4324/9780203405222

Dominique Moran and Anna Schliehe. 2017. 'Introduction: Co-production and Carceral Spatiality', in Moran and Schliehe (eds) Carceral Spatiality: Dialogues between Geography and Criminology. London: Palgrave-Macmillan. 1-12. https://doi.org/10.1057/978-1-137-56057-5 1

Hage, Ghassan. 2009. 'Waiting Out the Crisis: On Stuckedness and Governmentality', in Hage (ed) Waiting. Melbourne University Press, 97-106.

Heitzman, James. 2004. Network City: Planning the Information Society in Bangalore. New Delhi: Oxford University Press.

Nayar, Pramod K. 2017. The Extreme in Contemporary Culture: States of Vulnerability. Rowman and Littlefield.

Ramaswami, Sankar. 2012. 'Forces of truth: A struggle of migrant workers in Delhi', Ethnography 13(1): 57-70. https://doi.org/10.1177/1466138111432033

Roy, Shamindra Nath, Manish and Mukta Naik. 2017. 'Migrants in Construction Work: Evaluating their Welfare Framework'. New Delhi: Centre for Policy Research. www.cprindia.org. 
Shroff, Kaushal. 2020. "We are deserted": Migrant workers forced to walk hundreds of kilometres due to lockdown', The Caravan 26 March 2020. https:// caravanmagazine.in/news/we-are-deserted-migrant-workersforced-to-walk-hundreds-of-kilometres-due-to-lockdown

Slater, Joanna and Niha Masih. 'In India, the world's biggest lockdown has forced migrants to walk hundreds of miles home', Washington Post 28 March 2020. https://www.washingtonpost.com/world/asia_pacific/india-coronaviruslockdown-migrant-workers/2020/03/27/a62df166-6f7d-11 eaa156-0048b62cdb51 story.html

The Wire. '17 Migrant Workers, Kin Have Died Trying to Return Home Since the Lockdown Started', The Wire 29 March 2020. https://thewire.in/ rights/coronavirus-national-lockdown-migrant-workers-dead

\footnotetext{
${ }^{1}$ More recent reports inform that some deaths have occurred among the ones marching (Wire, '17 Migrant Workers...'). The government, as I write, has started arranging transportation for these workers returning home, and has assured them of food and sanitation if they stay on and do not travel.

2 Sector-wise statistics show that 100 million people move from rural to urban areas in search of employment (Aajeevika 2016).
} 